\title{
REVIEW
}

\section{Growth rate of tropical demersal fishes}

\author{
Rene J. Buesa* \\ Art and Science Department, Interamerican Center, Miami-Dade Community College, Miami, Florida, USA
}

\begin{abstract}
A review of available information showed that length at age of tropical demersal fishes is a function of the specific maximum length $\left(L_{M_{1}}\right)$, and that for species with similar $L_{M}$, differences in growth rates are direct consequences of their feeding habits. Fishes that depend on fish as main food source develop below average relative growth rates, while those that are either opportunistic or browser feeders grow faster. Invertebrate-eating fish grow in an intermediate pattern. These generalizations were derived from 53 age determinations of 37 tropical demersal fish species whose $L_{M}$ ranged from 13 to $270 \mathrm{~cm}$. During their first year, fishes with $\mathrm{L}_{M}$ of $<51 \mathrm{~cm}$ are able to grow up to $2 / 3$ of their $\mathrm{L}_{\mathrm{M}}$; those with $L_{M}$ from $51 \mathrm{~cm}$ to $100 \mathrm{~cm}$ attain almost $1 / 2$ of it, and those with larger $L_{M}$ are able to grow only up to near $1 / 3$ of their length limit. Relative length at age $\left(R_{\mathrm{lt}}\right)$ is significantly and inversely correlated with $\mathrm{L}_{\mathrm{M}}$, and when corrected with factors that describe the feeding regime of each species, the calculated $R_{l l}$ using the theoretical equations for ages 1 to $8 \mathrm{yr}$ old can be used to stratify fish length samples into age groups. The corrected theoretical equations were used to evaluate the age structure of 6 exploited demersal fish populations of Campeche Bank (Mexico), providing total mortality rates not statistically different from those simultaneously obtained with direct age determinations. Further, there was an inverse and significant correlation between the growth deceleration coefficient $(k)$ and the asymptotic length $\left(L_{\infty}\right)$ of the reviewed species.
\end{abstract}

\section{INTRODUCTION}

Growth of fish can be considered as no more than the individual production of mass as a net result of energy intake minus energy expenditures during all living activities.

After more than half a century of research on fish growth, especially in temperate waters, a great amount of knowledge has been gathered on the subject, including some generalizations presented in books (Brown 1962, Nikolski 1963) or in specialized conferences, such as the International Symposium on Age and Growth of Fish held in Iowa, USA, in June 1985. During this symposium, evidence was presented that maturation and spawning, crowding conditions and population density, photoperiod, productivity of the ecosystem, chemical components in the water, temperature fluctuations, amount and quality of food, as well

\footnotetext{
- Address for reprint requests: $4171 \mathrm{~W}$ 9th Lane, Hialeah, Florida 33012, USA
}

as almost any environmental biotic or abiotic factor, all have some sort of effect either on the actual growth rate of fish or in the way their hard structures can be interpreted during age determination studies. In the tropics, where temperatures are rather high and stable, there are extended spawning seasons contributing to the development of skewed and bimodal length distributions of cohorts (Isely \& Noble 1985).

Under tropical temperature conditions, many fish species show accelerated growth rates, which, however, frequently determine small final sizes because sometimes both sexes stop growing at an early age (Brown 1962).

Because of all these facts and because (Marr 1957) there can be subpopulations of a given fish species in any extensive marine area, each with their characteristic growth rates, questions arise about the validity of one or another method for age determination. Nikolski (1963) posed the question of conformity of age determinations from annual marks on different body structures (scales, bones, otoliths, etc.), as these are influenced by 
feeding conditions. He stressed the need to use several methods of age determination simultaneously in order to verify and validate results.

Many shortcuts to age determination have been developed because accurate estimations of growth and mortality rates require at least $1 \mathrm{yr}$ of intensive sampling and study after the actual selection and validation of an adequate solid structure for direct age determination. For example, Green (1970) calculated growth deceleration coefficient and total mortality rate by trial and error from theoretical relations between them, and equated asymptotic length to the largest fish sampled in the area.

In any event, without age determination there cannot be an adequate fisheries management policy, nor will we be able to understand patterns of fish growth and its relations with the ecosystem. The objective of this paper is to present a growth pattern found in tropical demersal fishes that can be used to stratify the length structure of fish populations into 'age groups' based only on the maximum length of the species and its food items in the area.

\section{METHODS}

This review includes 53 age determinations of 37 tropical demersal fish species done by validated and conventional direct and indirect methods. Maximum total length of species ranged from 13 to $270 \mathrm{~cm}$ (Table 1). Each length-at-age was expressed as a percentage (or relative length at age $=R_{l t}$ ) of the species maximum total length $\left(L_{M}\right)$ for the area where the fish came from. Record lengths, such as those compiled by the International Game Fish Association (Migdalski \& Fichter 1983), were not used because there was information on only 14 of the total 37 species reviewed, and even for that small group, the $L_{M}$ reported in the age determination studies for 12 cases was the same or even larger than the records. Furthermore, these records did not provide information on the food of the record-bearing fish.

For each age group (= all $R_{\mathrm{lt}}$ values for the same age for all species), a regression equation ( $\ln \mathrm{R}_{\mathrm{it}} v s \ln \mathrm{L}_{\mathrm{M}}$ ) was calculated by the least square method, including exponent confidence limits at the $p_{0.95}$ level. To evaluate results and comparisons, analyses of variance (ANOVA ' $F$ ' test) and Student's t-tests were used, with a minimal accepted significance level of $p_{0.95}$ and an $\alpha$ type error for both tests. Feeding habits of each species were obtained either from the age determination report or from other published information for the same area or from an area as close as possible to the one from where the fishes under study came.

Total mortality rates $(Z)$ were calculated for popula- tion samples during single fishing seasons (Buesa 1969).

References have been numbered to facilitate their inclusion in Table 1.

\section{RESULTS AND DISCUSSION}

It was found that the smaller the maximum length $\left(\mathrm{L}_{\mathrm{M}}\right)$ value (or 'growth limit') for a given species, the faster is the relative growth rate. Thus, during the first year of growth, species with $L_{M}$ of less than $51 \mathrm{~cm}$ are able to attain up to $65 \%$ of their $\mathrm{L}_{\mathrm{M}}$. Species with larger $L_{M}$ limits grow relatively less during their first year, viz., up to $44 \%$ in the group having $L_{M} 51 \mathrm{~cm}$ to $100 \mathrm{~cm}$, and up to only $29 \%$ in larger species.

The faster relative growth rate of small species $\left(\mathrm{L}_{M}\right.$ of $<51 \mathrm{~cm}$ ) is further demonstrated by the fact that after 2 to $6 \mathrm{yr}$, they grow up to 84 to $99 \%$ of their $\mathrm{L}_{\mathrm{M}}$, while larger species $\left(\mathrm{L}_{M}\right.$ of $>50 \mathrm{~cm}$ ) reach on average up to only $63 \%$ of their $L_{M}$ after $8 \mathrm{yr}$ of growth (Table 1).

$R_{\mathrm{lt}}$ vs $\mathrm{L}_{\mathrm{M}}$ correlations (Table 2) were highly significant $(p>0.999)$ for age groups 1 to 7 and very significant $\left(p_{>0.99}\right)$ for the $8 \mathrm{yr}$ age group, but as is usual in any set of naturally derived data, there is a certain degree of scatter in the relation $\ln R_{\mathrm{l} /} / \mathrm{ln} \mathrm{L}_{\mathrm{M}}$ (Fig. 1). Therefore, when the theoretical regression equations were used to back-calculate $R_{\mathrm{lt}}$ values for each species involved, it was found that the theoretical $R_{\mathrm{lt}}$ values agreed only with about $1 / 3$ of all species: there were some species whose real $R_{J t}$ was higher than the back-calculated value (about $1 / 4$ of all); the rest had smaller real $R_{1 t}$ values.

A back-calculation with only about $30 \%$ of cases in close agreement with reality was not good at all, so I undertook additional research and found that the species in good agreement had alimentary regimes where crustaceans, crustaceans and fish, or crustaceans and molluscs were the predominant food items.

For this specific group (Regime 3 in Table 3), I calculated all theoretical $R_{\mathrm{lt}}$ values for all species and ages and compared them with corresponding real $R_{l t}$ values. In order to bring theoretical values as close as possible to real ones, I had to multiply back-calculated $R_{1 t}$ values by an average correction factor of 1.03 for ages between 1 and 4 yr. For ages 5 to 8 , the correction factor averaged 1.00. I also found that the 2 correction factors were statistically different (ANOVA [F-test]: $F[1 ; 83]=5.78 ; p<0.05)$. The 2 age groups themselves (1 to 4 and 5 to $8 \mathrm{yr}$ ) were segregated as results of a significant analysis of variance $(F[1 ; 83]=4.15$; $\mathrm{p}<0.05$ ).

Fishes whose main food items are fish (Regime 1 in Table 3) need a feeding correction factor of 0.89 to bring into agreement real and theoretical $R_{\mathrm{lt}}$ values. 
Table 1. Relative length $\left(\mathrm{R}_{\mathrm{l}}=\left[\mathrm{l}_{\mathrm{l}} / \mathrm{L}_{\mathrm{M}}\right] \cdot 100\right)$ for ages 1 to 8 yr for 37 tropical demersal marine fish species. $\mathrm{L}_{M}$ : maximum length; FR: feeding regime; Ra: reference for age determination; Rf: reference for feeding regime (numbers are Ref. Nos. in 'Literature Cited'); Adm: age determination method; $\mathrm{L}_{x}$ : asymptotic length

\begin{tabular}{|c|c|c|c|c|c|c|c|c|c|c|c|c|c|c|c|}
\hline \multirow[t]{2}{*}{ Species } & \multirow{2}{*}{$\begin{array}{c}\mathrm{L}_{\mathrm{M}} \\
(\mathrm{cm})\end{array}$} & \multirow[t]{2}{*}{$\mathrm{FR}$} & \multirow[t]{2}{*}{ Zone } & \multicolumn{8}{|c|}{ Relative length at age } & \multicolumn{2}{|c|}{ Source } & \multirow[t]{2}{*}{ Adm ${ }^{*}$} & \multirow[t]{2}{*}{$\mathrm{L}_{\infty} / \mathrm{L}_{\mathrm{M}}$} \\
\hline & & & & 1 & 2 & 3 & 4 & 5 & 6 & 7 & 8 & $\mathrm{Ra}$ & Rf & & \\
\hline 1 Diplectrum macropoma & 13 & 3 & Panama & 51 & 83 & & & & & & & 5 & 5 & ot & 0.92 \\
\hline 2 Chaetodon miliaris & 14 & 4 & Hawaii & 65 & 84 & & & & & & & 6 & 61 & ot & 0.92 \\
\hline 3 Diapterus rhombeus & 20 & 4 & Isla Margarita & 49 & 75 & 88 & 95 & 98 & & & & 24 & 3 & $\mathrm{mp}$ & 1.01 \\
\hline 4 Diplectrum pacificum & 22 & 3 & Panama & 30 & 62 & 83 & & & & & & 5 & 5 & ot & 1.27 \\
\hline 5 Arius spixii & 29 & 3 & Isla Margarita & 44 & 61 & 73 & 82 & 88 & 92 & & & 23 & 20 & $\mathrm{mp}$ & 1.03 \\
\hline 6 Micropogomias undulatus & 30 & 4 & Louisiana & 47 & & & & & & & & 69 & 8 & sc & - \\
\hline 7 Haemulon aurolineatum & 34 & 2 & Campeche & 32 & 38 & 44 & 53 & 56 & 65 & & & 55 & 4 & sc & 0.80 \\
\hline 8 Haemulon aurolineatum & 36 & 2 & Campeche & 23 & 33 & 42 & 50 & 57 & 63 & 68 & 73 & 41 & 4 & ot & 1.09 \\
\hline 9 Beryx splendens & 36 & 3 & Japan & 25 & 53 & 72 & 83 & 91 & & & & 32 & 40 & ot & 1.05 \\
\hline 10 Micropogomias undulatus & 36 & 4 & Texas-Louisiana & 46 & 76 & & & & & & & 75 & 68 & sc & 0.89 \\
\hline 11 Calamus nodosus & 38 & 1 & Campeche & 23 & 36 & 45 & 53 & 61 & 68 & & & 41 & 65 & sc & 1.03 \\
\hline 12 Calamus nodosus & 38 & 1 & Campeche & 24 & 34 & 45 & 53 & 61 & 66 & 71 & 76 & 55 & 65 & sc & 1.06 \\
\hline 13 Calamus prondens & 39 & 1 & Campeche & 20 & 37 & 53 & 62 & & & & & 41 & 65 & ot & 0.95 \\
\hline 14 Calamus proridens & 39 & 1 & Campeche & 33 & 51 & 64 & 74 & 82 & 87 & 90 & 92 & 19 & 65 & sc & - \\
\hline 15 Cynoscion leiarchus & 40 & 4 & Ceara, Brazil & 46 & 65 & 78 & 88 & 95 & 99 & & & 54 & 20 & ot & 1.10 \\
\hline 16 Dentex macrophthalmus & 40 & 2 & Atlantic; 15 to $20^{\circ} \mathrm{S}$ & 27 & 43 & 55 & 63 & 73 & 77 & & & 71 & 71 & ot & 0.95 \\
\hline 17 Lutjanus synagris & 45 & 3 & NE Brazil & 27 & 44 & 58 & 69 & 78 & 85 & & & 1 & 9 & ot & 1.14 \\
\hline 18 Cynoscion nebulosus & 45 & 3 & Florida & 27 & 47 & 59 & 71 & 81 & 88 & 97 & & 34 & 38 & $\mathrm{sC}$ & - \\
\hline 19 Haemulon plumieri & 47 & 2 & Campeche & 25 & 38 & 51 & 55 & 62 & 66 & & & 17 & 4 & sc & 0.76 \\
\hline 20 Lutjanus synagris & 49 & 3 & Cuba & 35 & 43 & 49 & 59 & 67 & 79 & & & 16 & 9 & ot & 0.80 \\
\hline 21 Lutjanus griseus & 50 & 2 & Cuba, SW shelf & 34 & 47 & 57 & 65 & 71 & 75 & & & 21 & 14 & ot & - \\
\hline 22 Mugil curema & 52 & 4 & Cuba, SE shelf & 44 & 56 & 63 & 65 & & & & & 39 & 25 & ds & 0.77 \\
\hline 23 Cynoscion nebulosus & 54 & 3 & Cedar, Key, Florida & 24 & 39 & 49 & 60 & 71 & 80 & & & 34 & 38 & sc & - \\
\hline 24 Mugil cephalus & 60 & 4 & Florida & 23 & 38 & 50 & 62 & 73 & & & & 72 & 72 & ot & 1.75 \\
\hline 25 Micropogomias fournieri & 60 & 4 & Brazil & 33 & 40 & 53 & 57 & 62 & 65 & 67 & 70 & 2 & 68 & sc & 0.77 \\
\hline 26 Lutjanus griseus & 61 & 2 & Cuba, SE shelf & 23 & 36 & 46 & 55 & 62 & 67 & 70 & & 57 & 14 & ot & - \\
\hline 27 Haemulon album & 61 & 2 & Cuba, SW shelf & 18 & 27 & 37 & 47 & 56 & 68 & 77 & & 27 & 4 & ot & 0.82 \\
\hline 28 Pogomias cromis & 62 & 4 & USA & 37 & 47 & 66 & & & & & & 66 & 66 & sc & 0.95 \\
\hline 29 Micropogomias fournieri & 62 & 4 & Brazil & 27 & 39 & 51 & 60 & 68 & 75 & 82 & & 64 & 68 & ot & 1.27 \\
\hline 30 Calamus calamus & 65 & 2 & Campeche & 21 & 28 & 35 & 43 & 48 & 65 & 72 & 78 & 17 & 60 & sc & 0.82 \\
\hline 31 Cynoscion nebulosus & 66 & 3 & Fort Myers, Florida & 20 & 31 & 40 & 48 & 55 & 64 & 65 & 66 & 34 & 38 & sc & - \\
\hline 32 Lutjanus griseus & 70 & 2 & Cuba & 20 & 28 & 35 & 41 & 49 & 56 & 60 & & 59 & 14 & ot & - \\
\hline 33 Cynoscion nebulosus & 72 & 3 & Florida & 18 & 29 & 37 & 45 & 52 & 59 & 63 & 68 & 34 & 38 & sc & 1.96 \\
\hline 34 Calamus bajonado & 73 & 2 & Campeche & 19 & 33 & 45 & 54 & 62 & & & & 41 & 65 & ot & 2.32 \\
\hline 35 Calamus bajonado & 73 & 2 & Campeche & 31 & 40 & 45 & 48 & 57 & 63 & 68 & 75 & 17 & 62 & sc & 0.98 \\
\hline 36 Ocyuras chrysurus & 75 & 1 & Cuba & 16 & 24 & 29 & 33 & 39 & 43 & 47 & 48 & 58 & 13 & so & 0.61 \\
\hline 37 Ocyurus chrysurus & 80 & 1 & Cuba & 14 & 20 & 26 & 31 & 36 & 41 & 45 & 49 & 13 & 13 & ur & 1.03 \\
\hline 38 Lutjanus griseus & 80 & 2 & Florida & 20 & 30 & 33 & 40 & 45 & 53 & 59 & & 22 & 22 & SC & 1.55 \\
\hline 39 Lutjanus griseus & 80 & 2 & Florida & 19 & 26 & 33 & 38 & 43 & 49 & 56 & 61 & 67 & 14 & $\mathrm{sc}$ & 2.20 \\
\hline 40 Lutjanus purpureus & 82 & 1 & Brazil & 20 & 27 & 38 & 47 & 54 & 60 & 65 & 69 & 47 & 49 & ot & 1.09 \\
\hline 41 Bairdiella rhonchus & 85 & 3 & Florida & 16 & 28 & 34 & 42 & 48 & 54 & 59 & 65 & 38 & 37 & sc & - \\
\hline 42 Lutjanus griseus & 91 & 2 & Caribbean & 17 & 23 & 29 & 35 & 40 & 45 & 49 & 53 & 14 & 14 & If & 1.05 \\
\hline 43 Epinephelus morio & 91 & 3 & Campeche & 22 & 26 & 32 & 39 & 45 & 50 & 54 & 57 & 29 & 48 & ur & 1.26 \\
\hline 44 Elops saurus & 92 & 2 & Cuba, SE shelf & 23 & 27 & 33 & & & & & & 18 & 45 & $\mathrm{v}$ & 0.63 \\
\hline 45 Lutjanus campechanus & 100 & 3 & Campeche & 24 & 39 & 41 & 46 & 52 & & & & 26 & 6 & ot & 0.52 \\
\hline 46 Mycteroperca microlepis & 115 & 5 & Florida & 29 & 34 & 44 & 52 & 60 & 68 & 71 & 86 & 52 & 52 & ot & 1.16 \\
\hline 47 Lutjanus analis & 120 & 5 & Cuba & 27 & 35 & 46 & 50 & 51 & & & & 50 & 50 & ot & 0.57 \\
\hline 48 Lutjanus aya & 120 & 3 & Campeche & 20 & 25 & 29 & 31 & 33 & 38 & 46 & 55 & 17 & 60 & sc & 0.87 \\
\hline 49 Epinephalus striatus & 122 & 3 & Cuba & 24 & 29 & 32 & 38 & 44 & 46 & 52 & 54 & 11 & 11 & sc & 1.02 \\
\hline 50 Lutjanus cyanopterus & 150 & 3 & Cuba & 21 & 28 & 37 & 40 & 41 & & & & 11 & 56 & ot & 0.46 \\
\hline 51 Centropomus undecimalis & 150 & 2 & Florida & 11 & 29 & 33 & 39 & 45 & 50 & 55 & & 74 & 74 & ot & 0.58 \\
\hline 52 Sphyraena barracuda & 190 & 1 & Florida & 11 & 19 & 25 & 30 & 35 & & & & 70 & 70 & sc & 0.58 \\
\hline 53 Tarpon atlanticus & 270 & 1 & Brazil & 20 & 25 & 29 & 33 & 37 & 40 & 43 & 46 & 46 & 44 & $\mathrm{sc}$ & - \\
\hline
\end{tabular}


Table 2. Regression equations between the relative length at age $t\left(R_{1 t}\right)$ and the maximum length ( $\left.L_{M}\right)$ for tropical demersal fishes aged 1 to 8 yr. $R_{l t}=$ (length at age/maximum length) $100 ; R_{l t}=a L_{M}{ }^{b} ; \ln R_{i t}=\ln a+b \ln L_{M}=\left(l_{t} / L_{M}\right) \cdot 100$. Back-calculation: $l_{t}$ $=\left(\right.$ anti ln $\left.\mathrm{R}_{1 \mathrm{t}} \cdot \mathrm{L}_{\mathrm{M}}\right) / 100, \mathrm{a}=$ intercept $; \mathrm{b}=$ slope $; \mathrm{df}=$ degrees of freedom; $\mathrm{r}=$ correlation coefficient; $\mathrm{t}=\mathrm{age}$

\begin{tabular}{|c|c|c|c|c|c|c|c|}
\hline $\mathrm{t}$ & a & $\mathrm{b}$ & I & $\mathrm{df}$ & Significance & $\ln a$ & Confidence limits for $b\left(p_{0.95}\right)$ \\
\hline 1 & 156.283 & -0.4470 & -0.712 & 52 & $7.31^{\cdots}$ & 5.05170 & -0.327 to -0.567 \\
\hline 2 & 268.219 & -0.4851 & -0.805 & 51 & $9.69^{\cdots}$ & 5.59180 & -0.387 to -0.583 \\
\hline 3 & 307.441 & -0.4668 & -0.789 & 48 & $11.46^{\cdots} \cdot$ & 5.72827 & -0.364 to -0.570 \\
\hline 4 & 331.875 & -0.4501 & -0.807 & 45 & $9.38 \cdots$ & 5.80475 & -0.354 to -0.547 \\
\hline 5 & 350.344 & -0.4345 & -0.810 & 43 & $9.05^{\cdots}$ & 5.85889 & -0.340 to -0.529 \\
\hline 6 & 327.332 & -0.3991 & -0.759 & 35 & $6.59 \cdots$ & 5.79095 & -0.284 to -0.514 \\
\hline 7 & 263.160 & -0.3346 & -0.717 & 25 & $5.04^{\cdots}$ & 5.57275 & -0.204 to -0.465 \\
\hline 8 & 211.000 & -0.2716 & -0.625 & 18 & $3.39^{\cdots}$ & 5.35199 & -0.115 to -0.428 \\
\hline
\end{tabular}

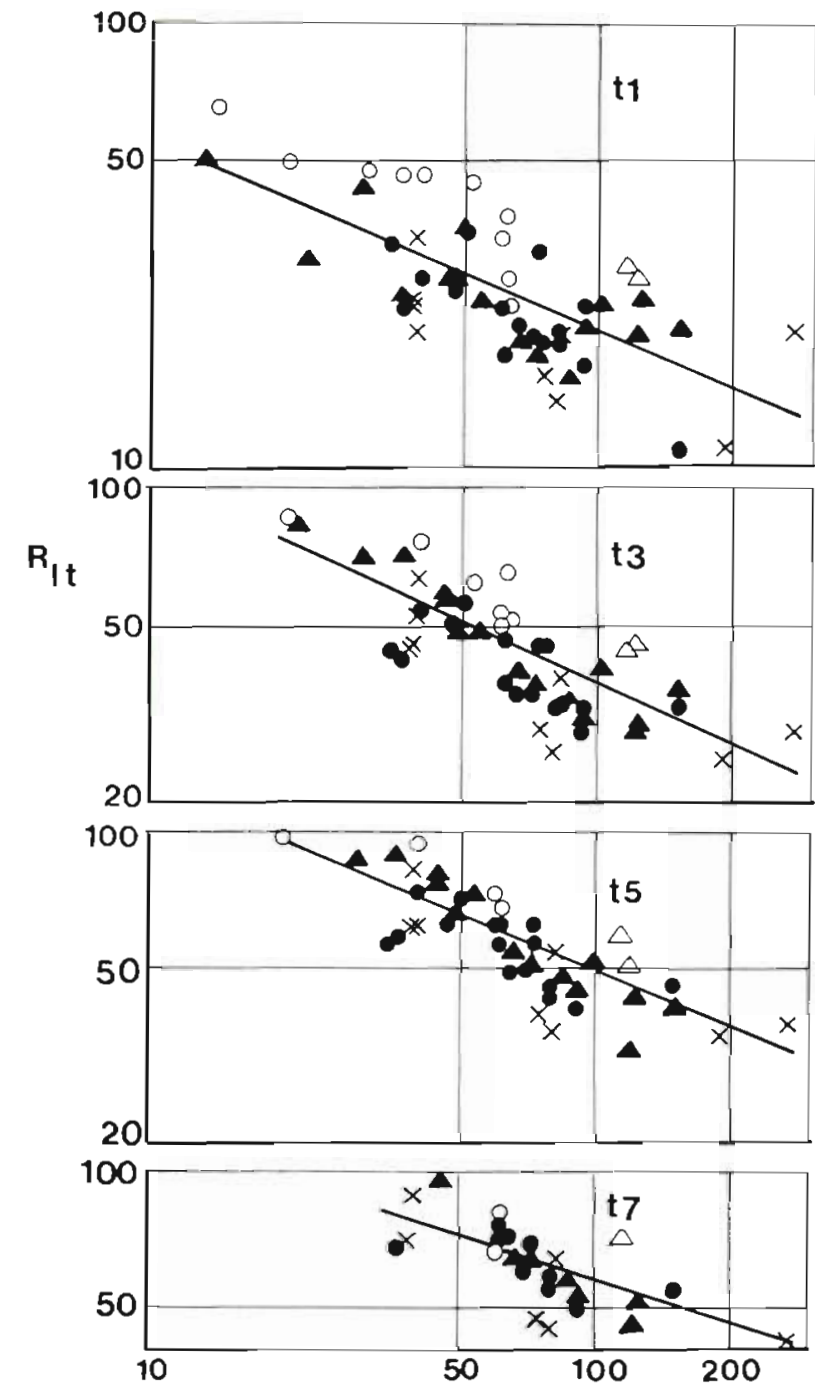

$L_{m}(\mathrm{~cm})$

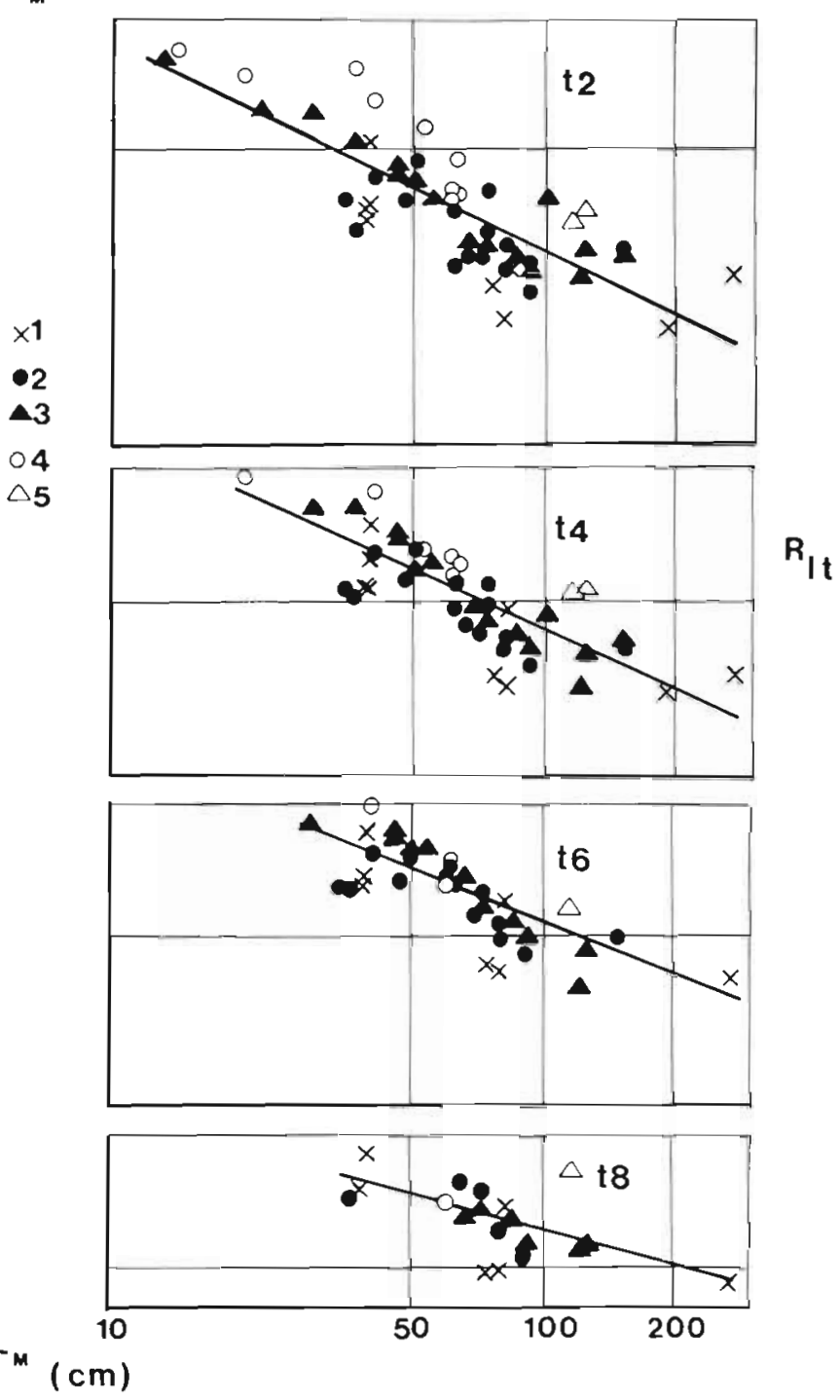

Fig. 1. Logarithmic relation between relative length $\left(R_{l t}=\left[1_{t} / L_{M}\right] \cdot 100\right)$ at each age $(t)$, and maximum length ( $L_{M}$; cm) of some tropical demersal marine fish species, from age 1 to 8 yr. Feeding regimes (from 1 to 5 ) are defined in Table 3 
Table 3. Alimentary regime correction factors for calculated relative lengths at age $t\left(R_{1 t}\right.$ calc). Invertebrates are defined as invertebrates other than crustaceans and molluscs. $n$ : number of species included in each alimentary regime

\begin{tabular}{|c|c|c|c|c|c|c|c|}
\hline \multirow[t]{2}{*}{ Regime } & \multirow[t]{2}{*}{$\mathrm{n}$} & \multirow[t]{2}{*}{$\begin{array}{l}\text { Component items of the } \\
\text { alimentary regime }\end{array}$} & \multicolumn{3}{|c|}{$\begin{array}{l}\text { Correction factors for } \\
\text { different age groups }\end{array}$} & \multirow{2}{*}{$\begin{array}{l}\text { Significance between } \\
\text { correction factors } \\
\text { for age groups }\end{array}$} & \multirow{2}{*}{$\begin{array}{l}\text { Mean caloric con- } \\
\text { tents of alimentary } \\
\text { regime } \\
\left(\mathrm{kcal} \mathrm{g}^{-1} \text { dry wt) }\right.\end{array}$} \\
\hline & & & 1 to 4 & 5 to 8 & 1 to 8 & & \\
\hline 1 & 9 & $\begin{array}{l}\text { Fish/invertebrates or molluscs/inver- } \\
\text { tebrates in a } 3: 1 \text { ratio; or crusta- } \\
\text { ceans/molluscs }+ \text { invertebrates in } \\
\text { even proportions }\end{array}$ & 0.87 & 0.91 & 0.89 & $F(1 ; 53)=0.52^{\mathrm{ns}}$ & 4.27 \\
\hline 2 & 16 & $\begin{array}{l}\text { Invertebrates alone; or crustaceans } \\
\text { and invertebrates in similar pro- } \\
\text { portions; or fish/crustaceans in } 2: 1 \text { or } \\
3: 1 \text { ratios; or molluscs/crustaceans at } \\
3: 1 \text { ratio }\end{array}$ & 0.90 & 0.96 & 0.93 & $F(1 ; 85)=3.84^{\mathrm{ns}}$ & 4.11 \\
\hline 3 & 16 & $\begin{array}{l}\text { Crustaceans alone, or fish and crusta- } \\
\text { ceans in similar proportions; or crus- } \\
\text { taceans/fish in ratios up to } 3: 1 \text {; or } \\
\text { crustaceans and molluscs in even } \\
\text { proportions }\end{array}$ & 1.03 & 1.00 & 1.02 & $F(1 ; 83)=5.78^{\circ}$ & 4.27 \\
\hline 4 & 10 & $\begin{array}{l}\text { Detritus + plant material and micro- } \\
\text { crustaceans alone; or with crusta- } \\
\text { ceans and/or molluscs; or with added } \\
\text { molluscs alone }\end{array}$ & 1.28 & 1.14 & 1.24 & $F(1 ; 43)=5.00^{\circ}$ & 2.37 \\
\hline 5 & 2 & Opportunistic predators & 1.37 & 1.34 & 1.36 & $\mathrm{~F}(1 ; 11)=0.27^{n \mathrm{~s}}$ & 3.91 \\
\hline
\end{tabular}

This correction factor is not statistically different for the 2 previously segregated age groups. The other group with back-calculated $R_{\mathrm{lt}}$ values greater than real ones consisted of fishes with an alimentary regime composed mainly of shellfishes or both shellfishes and finfishes (Regime 2; Table 3) with a general correction factor of 0.93 without statistical difference between the 2 segregated age groups.

Those species with back-calculated $R_{11}$ smaller than real ones had to be corrected by factors of $>1$. Fishes of food Regime 4 (mainly browser fishes) have correction factors of 1.28 and 1.14 for ages 1 to 4 and 5 to $8 \mathrm{yr}$ respectively, the 2 correction factors being statistically different $(F[1 ; 43]=5.00 ; p<0.05)$.

The last group (Regime 5) was composed of opportunistic feeding fishes, and the average correction factor needed to increase back-calculated to real $R_{\mathrm{lt}}$ values was 1.36 , with no statistical difference between the 2 segregated age groups (Table 3 ).

Using known calorific values for all food items (Garcia del Barco 1975) I found that the first 3 alimentary regimes had similar energy contents (Table 3 ), so correction factors of $<1$ for alimentary Regimes 1 and 2 compensate for a slower than theoretical relative growth rate caused by the energy needed to prey on those items and not because of the energy contents of the items themselves. In that sense, it is safe to assume that alimentary Regime 1 determines high energy expenditure because of 'hunting' for food items, especially when fishes prevail in the diet.

Although close to 1 , the correction factor for Regime 2 reflects a combination of hunting energy losses (partial predation on fish species) with the low energy contents of whole invertebrates because of their exoskeletons and conchs.

For Regime 3, where actual and back-calculated relative growth rates closely agree, an overall correction factor of 1.02 can mean a balance between moderate hunting expenses and food items of adequate energy contents for those expenses.

Regime 4 has the lowest caloric content of all, but this negative factor is more than compensated by the very low energy needed for feeding activities and by the great availability of food items (mainly detritus, microcrustaceans, and plant material). Since larger fish in this group grow in closer agreement to theoretical values than smaller ones (larger correction factor for smaller fish), it may be concluded that this type of browser feeding is more efficient during the first $4 \mathrm{yr}$ of life.

The last feeding group (Regime 5; Table 3) with the largest general correction factor is composed of oppor- 
tunistic fishes, those who eat almost whatever they come across. Their high growth rate may be due to this type of feeding habit which allows for a maximum of possibilities in terms of an almost endless source of food items. Another fact that could account for the high growth correction factor may be that one of the species (Mycteroperca microlepis) is quite sedentary and parsimonious, and is likely to have a low metabolic rate, enabling it to grow more efficiently.

The feeding correction factors calculated for the 5 alimentary regimes may be used as quantified indirect evidence of the importance that both food quality and energy needed to feed have on the growth of fish. When all feeding correction factors were compared, I found that between all of them there was a highly significant difference $(\mathrm{F}[4 ; 281]=55.35 ; \mathrm{p}<0.001)$ eliminating the possibility that the food grouping could be a consequence of chance.

Since there is an aiready known relation between fish feeding expenses and food items (Ivlev 1964), the importance of the feeding correction factors is that they are figures compensating for differences in growth as result of feeding habits. These findings support the need for correlating physiological and ecological variables and the general 'way of life' of each species to growth studies (Moreau 1985).

I content that age determinations cannot be adequately validated without a simultaneous study of feeding habits of the species in the same area. There is sound evidence indicating that ring formation in otoliths is affected by below-average feeding levels (Holt 1985, Jones 1985). Direct and 'validated' age determination methods for fishes always rely on the subjective interpretation of checks on hard structures (Casselman 1985), and it may be because of this interpretation that age determinations for a species frequently vary between authors. Food availability and quality also account for differences between areas. In this review, different lengths at the same age were found for Haemulon aurolineatum, Calamus nodosus, C. proridens, C. bajonado, Lutjanus synagris, L. griseus, Cynoscion nebulosus and Ocyurus chrysurus (Table 1). The differences amounted to up to $13 \%$ of $R_{1 t}$ for 2 age determinations in the same species (C. proridens) studied in the same area (Campeche Bank, Mexico). This difference in relative growth rate corresponds to the first year which is known as the most important pre-reproductive growing period for tropical fishes (Buesa 1975a). In aging tropical fish, there are additional difficulties when the study is based on only one hard structure, frequently requiring the support of other corroborating techniques to obtain reliable results (Whitelaw 1985).

Because of the information presented in this paper, one can identify a growth pattern for demersal tropical fishes in intimate relation with maximum total length and the feeding habits of each species. It would be interesting to test the procedure in reverse.

As a primary approach for a rough evaluation of the stock characteristics of a fish population, its age structure' could be assessed based on the maximum length of the species in the area, its food components, and a representative length sample. The regression equations will provide the relative length at each age that has to be corrected by the feeding factor to obtain the final length-at-age values for the species in that area.

Following this outlined procedure, I studied 6 demersal fish species from the Campeche Bank trawl fisheries (Table 4). The length composition of each species in the catches (not in the landings) were grouped in 2 sets of data: one based on direct age determinations and the other using the outlined shortcut for indirect age determination. Total mortality rates (Z) were calculated for the species in each set of age grouping. The average $Z$ value derived from the direct age determinations was $Z=0.89$ and a value of $Z=$

Table 4. Age structure and total mortality (Z) of 6 demersal fish populations from Campeche Bank (Mexico) as determined both by direct age methods and by back-calculation of relative length at age $\left(R_{l t}\right)$ for corresponding maximum lengths $\left(L_{M}\right)$ and feeding habits of the species involved

\begin{tabular}{|c|c|c|c|c|c|c|c|}
\hline \multirow[t]{2}{*}{ Species } & \multirow[b]{2}{*}{$\mathrm{L}_{M}(\mathrm{~cm})$} & \multicolumn{3}{|c|}{ Age by direct methods } & \multicolumn{3}{|c|}{ Age by backcalculation } \\
\hline & & $\begin{array}{l}\text { Modal } \\
\text { age }\end{array}$ & $\begin{array}{l}\text { Maximum } \\
\text { age }\end{array}$ & $Z^{\bullet}$ & $\begin{array}{l}\text { Modal } \\
\text { age }\end{array}$ & $\begin{array}{l}\text { Maximum } \\
\text { age }\end{array}$ & Z' \\
\hline Calamus nodosus & 38 & $3+$ & $8+$ & 0.5 & $3+$ & $8+$ & 0.4 \\
\hline Calamus proridens & 39 & $2+$ & $6+$ & 1.7 & $2+$ & $6+$ & 1.9 \\
\hline Lutjanus synagris & 49 & $2+$ & $6+$ & 1.2 & $2+$ & $6+$ & 1.6 \\
\hline Ocyurus chrysurus & 75 & $1+$ & $7+$ & 1.4 & $1+$ & $8+$ & 1.0 \\
\hline Epinephelus morio & 91 & $4+$ & $9+$ & 0.15 & $6+$ & $>8+$ & 0.27 \\
\hline Epinephelus striatus & 122 & $1+$ & $9+$ & 0.4 & $1+$ & $8+$ & 0.8 \\
\hline
\end{tabular}


0.99 was obtained with the indirect procedure. These 2 sets of $\mathrm{Z}$ values were not statistically different at a probability level of $\mathrm{p}>0.50\left(\mathrm{t}_{5}=0.79, \mathrm{~ns}\right)$

This result is less impressive than I would like it to be especially since all the Campeche demersal species were included in the calculation of both the regression equations and the feeding correction factors. Nevertheless, this indirect length/age grouping of a representative sample of a fish population could be used in many ways. For instance, in a new area under actual or potential exploitation, it would be more than useful to know, at least, if the modal class in the population is young or old, or if there are many age classes or only a few, with all the vulnerability implications that these differences involve.

This type of information is of great importance for fishery management and could be approximately assessed by using the regression equations that describe the growth pattern of tropical demersal fish, knowing only what size they can reach and what they eat in a given area.

I am aware that age determination involves an unpredictable degree of uncertainty, and does not justify by itself the introduction of additional guessing in the process, which is to be expected if this indirect age determination shortcut is used. However, in age determination of fishes a gain in accuracy involves additional effort, expense, and time, something that for practical or economical causes cannot be accomplished in areas where a supply of additional food is urgently needed, or where commercial exploitation has to be developed and cannot wait for long-term studies of the resources involved.

On the other hand, one can also ask: how much more accurate will the results be from a conventional direct age determination method? Trying to answer this question, I compared 2 of the von Bertalanffy's equation parameters: $L_{\infty}$ (asymptotic length) and $k$ (coefficient of growth rate decrease). $\mathrm{L}_{\infty}$ was known from almost all the reviewed papers, and it rendered an average value of $72.4 \mathrm{~cm}$. Using $R_{\mathrm{lt}}$ back-calculated and corrected for the feeding regimes, I calculated a new $L_{\infty}$ for each the same species, with a general average value of $68.0 \mathrm{~cm}$, only $6 \%$ different to the true $\mathrm{L}_{\infty}$ ' from the original papers. These 2 average $\mathrm{L}_{\infty}$ values proved not to be statistically different $\left(t_{78}=0.37\right.$; $p>0.20$ ). In the same way, I also calculated an average value of $k=0.32$ from the original age information, and another of $k=0.25$ using the shortcut procedure. Those $2 k$ values were also not statistically different $\left(\mathrm{t}_{78}=1.19 ; \mathrm{p}>0.70\right)$.

I investigated an additional relation between $L_{\infty}$ and $k$, finding that: $k=a L_{\infty}^{b}$ which resulted in $k$ being smaller for larger $\mathrm{L}_{\infty}$ values, as could be expected for a parameter that describes how slowly a fish ceases to grow or how fast it is able to get to its maximum theoretical length. Using natural logarithms, I found that the parameters for this relation are: $\mathrm{a}=9.43591$, $\mathrm{b}=-0.95657$ with a very significant inverse correlation coefficient $(r=-0.7844 ; \mathrm{p}<0.01)$.

Reynolds (1985) has also stated that fishes grow more slowly as they become larger, and that during their life span they reach a certain percentage of their maximum length. He used information from species whose maximum lengths ranged from $50 \mathrm{~cm}$ to $170 \mathrm{~cm}$ only and concluded that the relative length increment (growth) between age ' $t$ ' and age ' $t+1$ ' had an arithmetic (linear) relation with the relative length at age ' $t$ '. Reynolds did not try to use this information in any way and pointed out that further investigations were needed to include larger species. My approach is different because not only do I present a growth pattern from fishes with maximum lengths ranging from $13 \mathrm{~cm}$ to $270 \mathrm{~cm}$, but I also propose to use it as a shortcut to describe the age structure of any tropical demersal fish population.

This age determination shortcut was used as the only way to establish the age structure of 2 grunt species (Haemulon bonariense and H. sciurus) from the Southwestern Cuban shelf (Buesa 1981c) with satisfactory results both from the management and fishing points of view.

According to this information, especially in relation to the state of the art of direct age determination methods, it can be concluded that it is neither too risky nor too inaccurate to try to identify the age structure of a fish population based on representative population samples and an indirect length-at-age knowledge derived from information on both maximum length and feeding habits of the species in a given area. Being able to determine length-at-age by solving simple exponential equations that correlate maximum specific lengths with relative length at each age from 1 to $8 \mathrm{yr}$ is a real shortcut that would permit tentative fish assessments in less than $1 / 12$ of the time needed for an always mandatory first age determination by any conventional method, needing to be corroborated later. Feeding habits of the species under study, required to determine the feeding correction factor for growth, should be obtained simultaneously from the fishes sampled in the area. All stomach contents should be pooled for a later sorting into 6 large categories: crustaceans; molluscs; other invertebrates; fishes; plants; and bottom material. Their relative abundance will be determined as a percentage of the total weight of all pooled samples, as has been determined to be the fastest and most reliable way to assess the general feeding habit of fish species (Buesa 1975c).

I hope that this approach to age determination will prove to be useful for those who in a very short period 
of time and with tight research budgets need to produce a first assessment of the fishing potential of tropical demersal fish population.

Acknowledgements. The author expresses his gratitude to Ms Betty Inclan of the Interamerican Center of Miami-Dade Community College for the correction of grammar in this article.

\section{LITERATURE CITED}

Alegria, J. R., de Menezes, M. F. (1970). Edad y crecimiento del ariaco, Lutjanus synagris (Linnaeus), en el Nordeste del Brasil, Arq. Cienc. Mar. 10 (1): 65-68 (Ref. \# 1)

Anonymous (1964). Conocimientos actuales sobre la pesca y biologia de las especies marinas de importancia comercial en el Sur del Brasil. CARPAS Doc. Tec. 1: 1-19 (Ref. \# 2)

Austin, H. M. (1971). Some aspects of the biology of the rhomboid mojarra Diapterus rhombeus in Puerto Rico. Bull. mar. Sci. 21 (4): 886-903 (Ref. \# 3)

Billings, V. C., Munro, J. L. (1974). The biology, ecology and bionomics of Caribbean reef fishes: Pomadasyidae (grunts). Res. Rep. Zool. Dpt. Univ. West Indies 3: 1-128 (Ref. \# 4)

Bortone, S. A. (1977). Observations on the life history of Diplectrum pacificum and D. macropoma (Pisces, Serranidae) from the Bay of Panama. Pacif. Sci. 31 (1): 49-60 (Ref. \# 5)

Bradley, E., Bryan, C. E. (1975). Life history and fishery of the red snapper (Lutjanus campechanus) in the Northwestern Gulf of Mexico: 1970-1974. Proc. Gulf Caribb. Fish. Inst., Ann. Sess. 27: 77-106 (Ref. \# 6)

Brown, M. E. (1962). Experimental studies on growth. In: Brown, M. E. (ed.) The physiology of fishes. Academic Press, New York, p. 361-400 (Ref. \# 7)

Buesa, R. J. (1969). Estimacion de la mortalidad total (Z). INP/ CIP, Cuba; Reun. Bal. Trab. CIP 1: 1-6 (Ref. \# 8)

Buesa, R. J. (1970). La biajaiba y su trama alimentaria. INP/ Cuba; Mar y Pesca 54: 24-29 (Ref. \# 9)

Buesa, R. J. (1975a). Epocas de desove de peces cubanos. INP/ CIP, Cuba: Res. Invest. 2: 73-74 (Ref. \# 10)

Buesa, R. J. (1975b). Datos sobre la edad de peces cubanos. INP/CIP, Cuba; Res. Invest. 2: 76-78 (Ref. \# 11)

Buesa, R. J. (1975c). Resumen sobre la alimentacion de peces cubanos. INP/CIP, Cuba; Res. Invest. 2: 85-87 (Ref. \# 12)

Buesa, R. J. (1981a). Biologia y pesca de la rabirrubia (Ocyurus chrysurus). MIP/CIP, Cuba. In: Baisre, J. A., Paez, J. (ed.) Los recursos pesqueros del archipielago Cubano. FAO-WECAF Stud. 8 (Ref. \#13)

Buesa, R. J. (1981b). Biologia y pesca del caballerote (Lutjanus griseus) y la cubera (L. cyanopterus). MIP/CIP, Cuba. In: Baisre, J. A., Paez, J. (ed.) Los recursos pesqueros del archipielago Cubano. FAO-WECAF Stud. 8 (Ref. \# 14)

Buesa, R. J. (1981c). Biologia y pesca de roncos. MIP/CIP Cuba. In: Baisre, J. A., Paez, J. (ed.) Los recursos pesqueros del archipielago Cubano. FAO-WECAF Stud. 8 (Ref. \# 15)

Buesa, R. J., Olaechea, A. (1970). Estudios sobre la biajaiba: Zona B y area de Diago Perez. INP/CIP, Cuba; Res. Invest. p. 25 (Ref. \# 16)

Capote, A. M. (1971). (Sobre la edad de los peces bentonicos principales comerciales del Banco de Campeche) Sovietsko-Cubinskii Ribojoziaistveniie Issledovaniia Moscow. Pishchevaja Promyshlennost. 3: 77-80 (Russian) (Ref. \# 17)
Carles, C. A. (1967). Datos sobre la biologia del banano, Elops saurus Linnaeus (Teleostomi: Elopidae). INP/CIP, Cuba; Contr. (27): 1-53 (Ref. \# 18)

Casselman, J. M. (1985). Age determination of fish from calcified structures: old problems and new approaches. Int. Symp. Age \& Growth Fish, Abstracts: 35 (Ref. \# 19)

Cervigon, F. (1966). Los peces marinos de Venezuela. Caracas, Fund. La Salle de Ciencias Nat., Tomos 2 (Ref \# 201

Claro, R., Bustamante, G. (1977). Edad y crecimiento del caballerote Lutjanus griseus (Linnaeus) en la plataforma suroccidental de Cuba. Acad. Ciencias Cuba; Inst. Oceanol., Informe Cientif. Tec. (12): 1-11 (Ref. \# 21)

Croker, R. A. (1962). Growth and food of the gray snapper Lutjanus griseus in Everglades Park. Trans. Am. Fish Soc. 91 (4): 379-383 (Ref. \# 22)

Etchevers, S. L. (1978a). Contribution to the biology of the sea catfish, Arius spixii (Agasiz) (Pisces, Ariidae), South of Margarita Island, Venezuela. Bull. mar. Sci. 28 (2): 381-385 (Ref. \# 23)

Etchevers, S. L. (1978b). Contribution to the biology of Diapterus rhombeus (Cuvier) (Pisces, Gerridae), South of Margarita Island, Venezuela. Bull. mar. Sci. 28 (2): 385-389 (Ref. \# 24)

Furtado, E. (1968). Alguns dados sobre a alimentacao de jovens do genero Mugil Linnaeus no Estado do Ceara. Arq. Est. Biol. Mar. Univ. Ceara 8 (2): 173-176 (Ref. \# 25)

Futch \& Bruyer (1976). Paper on Lutjanus campechanus published by the University of Texas about fishery resources of Campeche Bank and the Caribbean (Ref. \# 26)

Garcia, J. P. (1979). Datos preliminares sobre la edad y crecimiento del jallao (Haemulon album) en la zona suroccidental de la plataforma de Cuba. Acad. Ciencias/Inst. Oceanologia, Cuba; Res. Evento Cientif. (5) : 12 (Ref. \# 27)

Garcia del Barco, F. (1975). Contenido calorico de organismos acuaticos. INP/CIP, Cuba; Res. Invest. (2): 255-259 (Ref \# 28)

Gonzalez, P. D., Zupanovic, S., Ramis, H. E. (1974). Biologia pesquera de la cherna americana del Banco de Campeche INP/CIP. Cuba; Res. Invest. (1): 107-111 (Ref. \# 29)

Green, R. H. (1970). Graphical estimation of rates of mortality and growth. J. Fish. Res. Bd Can. 27 (1): 204-208 (Ref. \# 30)

Holt, S. A. (1985). Age and growth of larval red drum using otolith ring counts. Int. Symp. Age \& Growth Fish Abstracts: 87-88 (Ref. \# 31)

Ikenouye, H. (1969). Age determination by otolith of a Japanese alfonsin, Beryx splendens, with special reference to growth. J. Tokyo Univ. Fish. 55 (2): 91-98 (Ref. \# 32)

Isely, J. J., Noble, R. L. (1985). Use of daily otolith rings to interpret development of length distributions of young largemouth bass. Int. Symp. Age \& Growth Fish, Abstracts: 40-41 (Ref. \# 33)

Iversen, E. S., Tabb, D. C. (1962). Subpopulations based on growth and tagging studies of spotted seatrout Cynoscion nebulosus (Cuvier), in Florida. Copeia 1962 (3): 544-548 (Ref. \# 34)

Ivlev, V. S. (1964). Experimental ecology of the feeding of fishes. Yale University Press, Yale (Ref. \# 35)

Jones, C. (1985). Use of the otolith increment technique to age striped bass larvae. Int. Symp. Age \& Growth Fish, Abstracts: 89-90 (Ref. \# 36)

Juarez, M. (1968). Alimentacion de algunas especies de peces capturadas en la Hortigosa. Inst. Oceanol., mecanogr (Ref. \# 37)

Klima, E. F., Tabb, D. C. (1959). A contribution to the biology of the spotted weak fish, Cynoscion nebulosus (Cuvier) 
from Northwestern Florida, with a description of the fishery. State Fla. Brd. Conserv., Tech. Ser. (30): 1-25 (Ref. \# 38)

Lajonchere, L. S. A. (1976). Contribucion al estudio del ciclo de vida de Mugil curema Valenciennes in Cuvier et Valenciennes, 1836 (Pisces, Mugilidae). Univ. Habana, Ciencias, Serie 8, Invest. Mar. (28): 1-130 (Ref. \# 39)

Leon, M. E. de (1975). Regimen de alimentacion del Beryx splendens (pers. comm.) (Ref. \# 40)

Leon, M. E. de, Chtervakov, Yu. A. (Ms.). Determinacion de la edad de cuatro especies demersales del Banco de Campeche. INP/CIP, Cuba; mecanogr. (Ref. \# 41)

Lima, F. R. (1965). Crescimento do 'pargo' (Lutianus aya, Bloch, 1795) aspectos quantitativos, 1962/63. Bol. Est. Pesca 5 (2): 33-42 (Ref. \# 42)

Marr, J. C. (1957). Contributions to the study of subpopulations of fishes. U.S. Dept. Int., Fish Wild. Serv., Spec. Sci. Rep., Fish. (208): 1-129 (Ref. \# 43)

Menezes, M. F. de (1968a). Sobre a alimentacao de camurupim, Tarpon atlanticus (Valenciennes), no Estado do Ceara. Arq. Est. Biol. Mar. Univ. Fed. Ceara 8 (2): 145-149 (Ref. \# 44)

Menezes, M. F. de (1968b). Alimentacao de jovens da ubarama, Elops saurus Linnaeus, no Estado do Ceara. Ibidem 8 (2): 221-223 (Ref. \# 45)

Menezes, M. F. de, Paiva, M. P. (1966). Notes on the biology of tarpon Tarpon atlanticus (Cuvier \& Valenciennes) from coastal waters of Ceara state, Brazil. Ibidem 6 (1): 83-93 (Ref. \# 46)

Migdalski, E. C., Fichter, G. S. (1983). The fresh and salt water fishes of the world. Greenwich House, New York (Ref. \# 47)

Moe, M. A., Jr. (1969). Biology of the red grouper Epinephelus morio (Valenciennes) from the Eastern Gulf of Mexico. Fla. Dept. Nat. Res., Prof. Pap. Ser. (10): 1-95 (Ref. \# 48)

Monteiro, N. V., Barroso, L. (1963). Estudo sobre o ciclo sexual e o regimen alimentar do pargo. Bol. Est. Pesca 3 (11/12): 13-20 (Ref. \# 49)

Montes, M., Canas, R., Prieto, M. (1963). Estudios estadisticos y biologicos sobre el pargo criollo (Lutjanus analis): II. INRA/CIP, Cuba; mecanogr. (Ref. \# 50)

Moreau, J. (1985). Mathematical and biological expression of growth in fishes: recent trends and further developments. Int. Symp. Age \& Growth Fish., Abstracts: 34-35 (Ref. \# 51)

McErlean, A. J. (1963). Biology of Mycteroperca microlepis. State Fla. Brd. Conserv., Tech. Ser. (41): 1-29 (Ref. \# 52)

Nikolski, G. V. (1963). The ecology of fishes. Academic Press, London (Ref. \# 53)

Nomura, H. (1966). Idae e crecimento da pescada-branca, Cynoscion leiarchus (Cuvier) das aguas Cearenses. Arq. Est. Biol. Mar. Univ. Fed. Ceara 6 (2): 135-137 (Ref. \# 54)

Olaechea, A., Hernandez, C. (1975). Evaluacion de las poblaciones de jeniguano Haemulon aurolineatum y pez pluma Calamus nodosus en el Banco de Campeche. INP/ CIP, Cuba; Res. Invest. (2): 157-160 (Ref. \# 55)

Overko, S. (1967). Datos biologicos de especies comerciales cubanas. (Russian.) INP/CIP, Cuba; mecanogr. (Ref. \# 56)

Pedroso, B. (1978). Crecimiento y edad del caballerote Lutjanus griseus (Linnaeus) en Tunas de Zaza, Cuba. Univ. Habana, Centro Invest. Marinas, Trab. Diploma mecanogr. (Ref. \# 57)

Piedra, G. (1965). Datos sobre la biologia de la rabirrubia
Ocyurus chrysurus (Bloch). In: Bogdanov, A. S. (ed.) Investigaciones pesqueras sovietico-cubanas. Pashchevia Promyshlennost, Moscow 1: 267-284 (Russian) (Ref. \# 58)

Piedra, G. (Ms.). Articulo sobre caballerote. INP/CIP, Cuba; mecanogr., 1964 (Ref. \# 59)

Prosvirov, E., Varea, J. A. (Ms.). Datos de los viajes de los SRT-R al Banco de Campeche, campanas de 1963 a 1964. INP/CIP, Cuba; mecanogr. (Ref. \# 60)

Ralston, S. (1976). Age determination of a tropical reef butterflyfish utilizing daily growth rings of otoliths. Fish. Bull. 74 (4): 990-994 (Ref. \# 61)

Reynolds, J. B. (1985). Relative length: a comparative approach to fish growth. Int. Symp. Age \& Growth Fish., Abstracts: 69 (Ref. \# 62)

Rodrigues, M. S. de S. (1968). Idade e crescimento da cururuca, Micropogon fournieri (Desmarest, 1822) nas aguas cearenses. Arq. Est. Biol. Mar. Univ. Fed. Ceara 8 (1): 7-14 (Ref. \# 63)

Rodriguez, Z. (1962). Estudios estadisticos y biologicos sobre la biajaiba (Lutjanus synagris). INRAVCIP, Cuba; Notas Invest. (4): 1-91 (Ref. \# 64)

Ryzhov, V., Formoso, M. (1975). Ritmo de alimentacion de tres especies del genero Calamus (Sparidae) en el Banco de Campeche. INP/CIP, Cuba; Res. Invest. (2): 113-114 (Ref. \# 65)

Simmons, E. G., Brener, J. P. (1962). A study of redfish, Sciaenops ocellata, Linnaeus, and black drum, Pogomias cromis Linnaeus. Publs Inst. mar. Sci., Univ. Tex. 8: 184-211 (Ref. \# 66)

Starck (1971). Review on the biology of Lutjanus griseus. In: Claro R., Bustamante, G. (1977) Ref. \# 21 (Ref. \# 67)

Stickney et al. (1975). Information on feeding habits of Micropogomias undulatus and $M$. fournieri, cited by White, $M$. L., Chittenden, M. E. (1977) Ref. 75 (Ref. \# 68)

Suttkus, R. D. (1955). Movimientos estacionales y crecimiento de la corbina del Atlantico (Micropogon undulatus) a lo largo de la costa oriental de Louissiana. Proc. Gulf Caribb. Fish. Inst. 7: 151-158 (Ref. \# 69)

Sylva, D. P. de (1963). Systematics and life history of the great barracuda Sphyraena barracuda (Walbaum). Stud. Trop. Oceanogr., Univ. Miami (1); viii + 179 pp. (Ref. \# 70)

Terre, J., Corujo, C. H. (1975). Algunos aspectos biologicos y dinamicos del Dentex macrophthalmus (Bloch), un esparido del Atlantico Suroriental. INP/CIP, Cuba; Res. Invest. (2): 186-188 (Ref. \# 71)

Thompson, J. M. (1963). Synopsis of biological data on the gray mullet Mugil cephalus, Linnaeus, 1758. CSIRO Fish. Syn. (1), DFO-Si. SAST-1, 65 (1) (Ref. \# 72)

Ursin, E. (1967). A mathematical model of some aspects of fish growth, respiration, and mortality. J. Fish. Res. Bd Can. 24 (11): 2355-2453 (Ref. \# 73)

Volpe, A. V. (1959). Aspects of the biology of the common snook, Centropomus undecimalis (Bloch) of Southwest Florida. State Fla. Bd. Conserv., Tech. Ser. (31): 1-37 (Ref. \# 74)

White, M. L., Chittenden, M. E. (1977). Age determination, reproduction, and population dynamics of the Atlantic croaker, Micropogomias undulatus. Fish. Bull. U.S. 75 (1): 109-123 (Ref. \# 75)

Whitelaw, A. W. (1985). Aging of tropical fish species of North West Australia. Int. Symp. Age \& Growth Fish., Abstracts: 64-65 (Ref. \# 76) 